\title{
TRADISI DAN KELEMBAGAAN MASYARAKAT DALAM PENGELOLAAN SUMBERDAYA PESISIR DAN LAUT DI KOTA TIDORE KEPULAUAN, PROVINSI MALUKU UTARA
}

\section{(Traditions and Community Institutions in The Coastal and Marine Resource Management in City of Tidore Islands, North Maluku Province)}

\author{
Ruslan H.S. Tawari ${ }^{1 *}$, J.B. Paillin'1, Haruna1, \\ Stany R. Siahainenia ${ }^{1}$, Selfi Sangadji ${ }^{1}$, Abdul M. Angkotasan ${ }^{2}$
}

\author{
${ }^{1}$ Jurusan Pemanfaatan Sumberdaya Perikanan Fakultas Perikanan dan Ilmu Kelautan \\ Universitas Pattimura \\ ${ }^{2}$ Jurusan Manajemen Sumberdaya Perairan Fakultas Perikanan dan Ilmu Kelautan \\ Universitas Khairun \\ *donbilloland@ymail.com,bobby.b.paillin@gmail.com,haruna.unpatti@gmail.com, \\ stanysiahainenia@gmail.com,selfisangadji05@gmail.com,abd.motalibangkotasan@gmail.com \\ Corresponding author*
}

\begin{abstract}
ABSTRAK: Meningkatnya kesadaran global terkait pengelolaan lingkungan, ekosistem dan pemanfaatan sumberdaya perikanan menjadi pemicu dalam reaktualisasi tradisi dan kelembagaan masyarakat. Masyarakat Kota Tidore Kepulauan yang dikenal sebagai masyarakat adat dengan tradisi kelembagaan pesisir dan lautnya di Provinsi Maluku Utara, merupakan masyarakat yang memiliki tatanan lokal yang turun temurun dalam pemanfaatan sumberdaya pesisir dan laut dimaksud. Penelitian ini bertujuan untuk menganlisis eksistensi tradisi dan kelembagaan serta pengaruhnya terhadap pengelolaan sumberdaya pesisir dan laut di Kota Tidore Kepulauan. Penelitian ini dilaksanakan pada Juni- Agustus 2019, di Kota Tidore Kepulauan meliputi 2 desa dan 4 kelurahan yakni, Desa Mare Gam, Desa Maitara, Kelurahan Tomalou dan Kelurahan Mareku, Kelurahan Soasio dan kelurahan Dowora. Penelitian ini merupakan penelitian kualitatif, yang melibatkan teknik-teknik wawancara mendalam, observasi, dan dokumentasi. Analisis data dilakukan secara deskriptif kualitatif. Hasil Penelitian menunjukkan sampai saat ini masih terdapat lima kearifan lokal yang tetap terjaga oleh masyarakat Kota Tidore Kepulauan yang merupakan warisan dari para leluhur dalam pengelolaan sumbedaya pesisir dan laut, yakni Karo Kahiya (Memanggil Lumba Lumba), Fola Sow (Rumah Obat), Jere (Keramat), Cofa (Penangkaran Ikan) dan Saihu (Pemimpin/Nakoda dalam Operasi Penangkapan Ikan). Pendekatan pengelolaan sumberdaya pesisir dan lautan dengan tradisi dan kelembagaan telah memberikan dampak yang sangat signifikan (sangat efektif) bagi masyarakat setempat dalam pemanfaatan sumberdaya pesisir dan lautan yang berkelanjutan maupun pelestarian tradisi dan kelembagaan adat istiadat setempat.
\end{abstract}

Kata Kunci: Tradisi, kelembagaan, pengelolaan, sumberdaya, Tidore

ABSTRACT: Increasing of global awareness related to environmental management, ecosystems, and fisheries resources is a trigger in the reactualization of community traditions and institutions. People of Tidore Islands City, known as indigenous people with their coastal and marine institutional traditions in North Maluku Province, have a local order handed down in the utilization of the coastal and marine resources. This study aimed to analyze the existence of traditions and institutions and their effects on managing 
coastal and marine resources in the City of Tidore Islands. The research was conducted on June-August 2019 in the city of Tidore Islands. This research encompass 4 Subdistrict and 2 villages namely, Tomalou, Mareku, Soasio and Dowora Subdistrict as well as Mare Gam and Maitara village,. The research applied a qualitative method, which involves indepth interview techniques, observation, and documentation. Data were analysed using a qualitative descriptive analysis. The results of the study showed that there are five local wisdoms that are maintained by the people of Tidore Islands City nowadays. These local wisdom is a legacy from the ancestors in the management of coastal and marine resources, namely Karo Kahiya (Calling the Dolphins), Fola Sow (Lit. House of Medicine), Jere (Sacred), Cofa (Fish breeding) and Saihu (Leader/Fishing Master). The approach to management of coastal and marine resources with procedures or traditions and institutions contributed a significant impact (very effective) on local communities in relation to the sustainable use of coastal and marine resources. as well as the preservation of local traditions and customary institutions.

Keywords: Tradition, institutional, management, resources, Tidore

\section{PENDAHULUAN}

Reaktualisasi tradisi dan kelembagaan pada tatanan masyarakat pesisir pada saat ini terasa sangat dibutuhkan terutama dalam pengelolaan sumberdaya perikanan dan kelautan. Meningkatnya kesadaran global terkait pengelolaan lingkungan, ekosistem dan pemanfaatan sumberdaya perikanan menjadi pemicu dalam reaktualisasi tradisi dan kelembagaan masyarakat dimaksud. Satria \& Mony (2019), menjelaskan bahwa kesadaran ini beririsan dengan isu-isu lingkungan, kemiskinan, perubahan iklim dan kurang efektifnya pendekatan saintifik dalam memecahkan masaalah-masalah tersebut.

Berbagai praktek kegiatan pengelolaan sumberdaya perikanan dan kelautan yang bersifat tradisional, memiliki kelembagaan tersendiri pada masyarakat pesisir telah menjadi perhatian para peneliti seperti Sasi di Maluku (Gazper 2000; Latuconsina 2009; Talakua 2011; Supusepa 2012), pola pengelolaan berbasis kearifan lokal di Aceh, Kabupaten Kutai Timur, Warsamdin dan Lopintol, Distrik Teluk Mayalibit, Provinsi Papua Barat (Sulaiman, 2010; Juliani, 2014; Najamuddin et.al., 2015), kearifan tradisional awik-awik di Nusa Tenggara Barat (Irrubai, 2019) telah memberikan nuansa tersendiri dalam membangun paradigma baru pengelolaan sumberdaya pesisir dan laut.

Pada dasarnya setiap masyarakat memiliki adat-istiadat, nilai dan kebiasaan yang berbeda di setiap tempat (Sufia, dkk., 2016; Niman, 2019). Perbedaaan ini tentu saja berdampak pada perbedaan tata cara dalam pengelolaan lingkungan dan ekosistem pesisir dan laut di masing-masing daerah. Selain itu dalam pengelolaan lingkungan dan ekosistem pesisir dan laut juga tidak terlepas dari kondisi fisik, masyarakat dan budaya masyarakat itu sendiri (Dewi, 2018). Demikian halnya masyarakat Kota Tidore Kepulauan yang sebagian besar masyarakatnya $(90 \%)$ bermukim di pesisir pulau Tidore, Maitara, Mare dan Halmahera. Dalam melakukan aktivitas kesehariannya, masyarakat selalu menjadikan laut sebagai sumber mata pencaharian dalam tradisi dan kelembagaan adat setempat.

Secara geografis luas wilayah Kota Tidore Kepulauan sebesar $1,550.37 \mathrm{~km}^{2}$ yang terdiri dari 8 Kecamatan dengan jumlah penduduk pada tahun 2019 sebesar 101.414 jiwa (BPS Kota Tidore Kepulauan, 2020). Masyarakat Kota Tidore Kepulauan sejak dulu hingga sekarang masih mempertahankan tradisi dan kelembagaan dalam pengelolaan sumberdaya pesisir dan laut sebagai eksistensi nilai-nilai kearifan lokalnya, sebagai upaya pemanfaatan dan pelestarian sumberdaya pesisir dan laut. Hingga saat ini, kearifan lokal masyarakat Kota Tidore Kepulauan masih tetap terjaga yang merupakan warisan dari para leluhur dalam pengelolaan sumberdaya pesisir dan laut. Tradisi masyarakat pesisir Kota Tidore 
Kepulauan tersebut, merupakan salah satu nilai kearifan lokal yang patut dianalisis dengan pendekatan kelembagaan sebagai bagaian dari kesadaran global masyarakat adat dalam memanfaatkan dan melestarikan ekosistem perairan.

Masyarakat yang bermukim di daerah pantai sangat menggantungkan hidupnya pada pemanfaatan sumberdaya laut dan pantai. Berdasarkan hasil penelitian Ulfa (2018), perubahan iklim mempengaruhi kondisi sosial ekonomi nelayan karena masyarakat nelayan bergantung pada ekosistem laut yang mengalami perubahan akibat fenomena tersebut. Sehubungan dengan keberadaan masyarakat tersebut dan ketergantungannya pada ekosistem laut, maka perlu dilakukan pengelolaan lingkungan di wilayah laut dan pantai secara terpadu. Pengelolaan lingkungan secara terpadu artinya memiliki dampak yang efektif terhadap keseimbangan antara ekonomi dan ekologi. Berdasarkan hal tersebut maka muncullah bentuk pengelolaan yang lebih aplikatif (applicable) yang mudah diterapkan dan adaptif yang mudah disesuaikan (acceptable) (Dewi, 2018). Selanjutnya dikatakan bahwa salah satu bentuk pengelolaan wilayah pesisir yang mudah
DOI: https://doi.org/10.30598/TRITONvol16issue1page19-27

diterapkan dan sesuai yaitu pengelolaan berbasis masyarakat (community based management).

Pengelolaan berbasis masyarakat merupakan suatu sistem pengelolaan sumberdaya alam di suatu tempat, dimana masyarakat lokal terlibat secara aktif dalam proses pengelolaan sumberdaya alam yang terkandung didalamnya (Carter, 1996; CORMEP-LIPI, 1997; Nikijuluw, 2002; Persada, $d k k$., 2018). Penelitian ini bertujuan untuk menganalisis eksistensi tradisi dan kelembagaan serta pengaruhnya terhadap pengelolaan sumberdaya pesisir dan laut di Kota Tidore Kepulauan.

\section{METODE PENELITIAN}

Penelitian ini dilaksanakan pada bulan Juni-Agustus 2019 di Kota Tidore Kepulauan meliputi Desa Mare Gam, Desa Maitara, Kelurahan Tomalou, Kelurahan Mareku, Kelurahan Soasio dan Kelurahan Dowora (Gambar 1). Penelitian ini merupakan penelitian kualitatif (Cresswel, 2010), yang melibatkan teknik-teknik wawancara mendalam, observasi, dan dokumentasi.

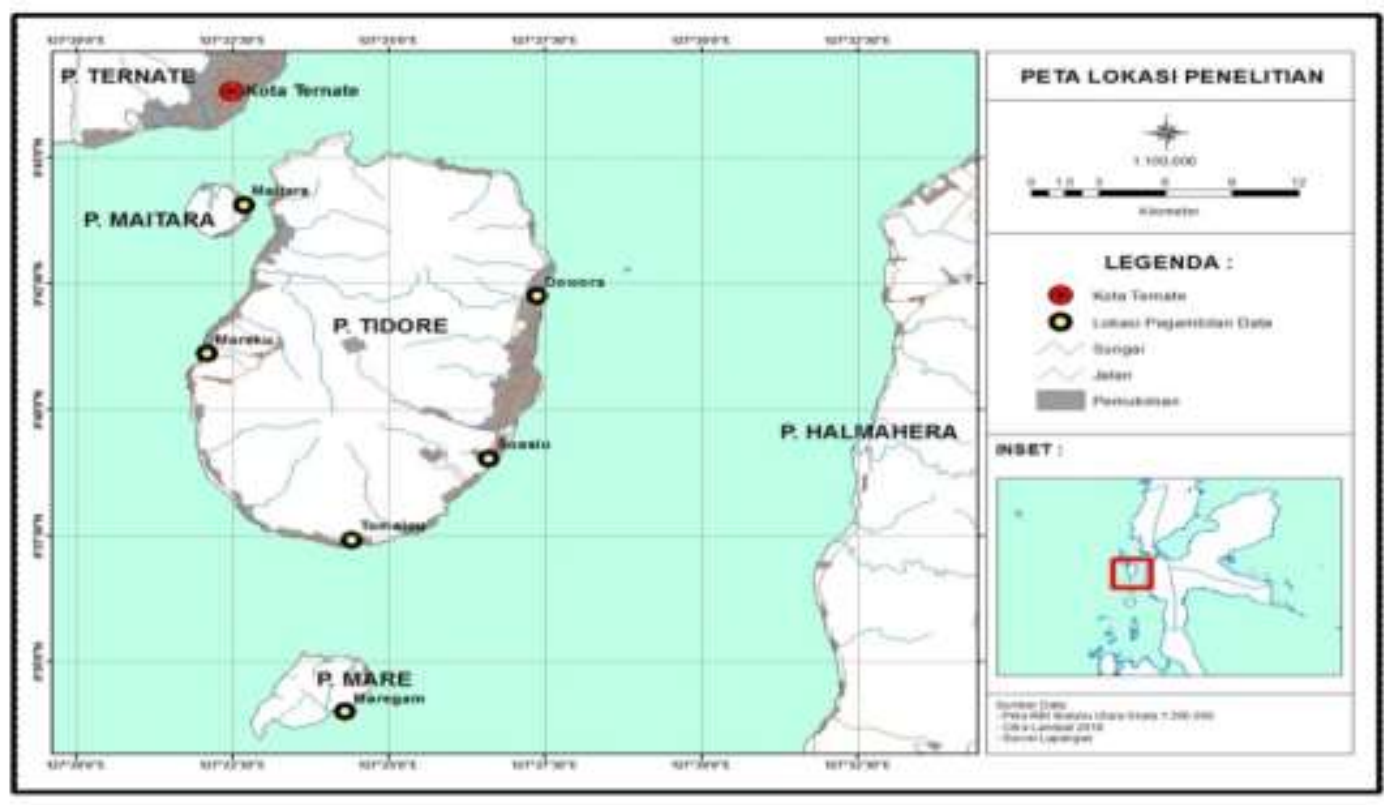

Gambar 1. Peta lokasi penelitian 
Pengumpulan data primer menggunakan metode pengamatan langsung di lapangan (Observation) dan wawancara mendalam (In dept interview) terhadap responden yang dilakukan secara purposive sampling (Sugiyono, 2018). Wawancara mendalam (In dept interview) dilakukan terhadap informan kunci sebesar 36 responden sebagai perwakilan masyarakat setempat. Perwakilan masyarakat terdiri dari tokoh adat berjumlah 2 responden, aparatur desa 1 responden dan nelayan 3 responden dari masing-masing desa dan kelurahan. Data sekunder diperoleh dari sumber-sumber laporan pemerintah daerah maupun hasil-hasil riset ilmiah berupa jurnal serta berbagai litertur yang berkaitan dengan penelitian ini. Penelitian ini menggunakan pendekatan deksriptif kualitatif dalam proses analisis datanya.

\section{HASIL DAN PEMBAHASAN}

\section{Tradisi dan Kelembagaan Adat}

Kota Tidore Kepulauan merupakan salah satu daerah kesultanan di Negara Kesatuan Republik Indonesia (NKRI) yang masih melestarikan warisan leluhur dalam upaya pengelolaan dan pelestarian sumberdaya pesisir dan laut berdasarkan adat dan tradisi yang telah terlembaga. Tradisi dan kelembagaan adat yang terdapat di Kota Tidore Kepulauan meliputi berbagai aturan yang terkait dengan tata kehidupan masyarakat, tata pemerintahan maupun tata kelola sumberdaya alam yang telah diimplementasikan oleh masyarakat setempat baik pada zaman kesultanan Tidore, maupun pada era pemerintahan modern sekarang ini. Secara administratif pemerintahan, masyarakat di lokasi penelitan berada di dalam naungan pengelolaan pemerintahan Kota Tidore Kepulauan, namun secara struktural kelembagaan adat berada di bawah kekuasaan Kesultanan Tidore.

Kelembagaan merupakan suatu aturan yang dikenal dan diikuti secara baik oleh anggota masyarakat, serta memberi naungan (liberty) dan meminimalkan hambatan (constraints) bagi individu atau anggota masyarakat (Suradisastra, 2008). Kelembagaan yag tertulis secara formal dijalankan dan ditegakkan oleh aparat pemerintah, sedangkan kelembagaan yang tidak tertulis secara formal seperti aturan adat dan norma yang dianut masyarakat. Kelembagaan juga merupakan fenomena sosial ekonomi berkaitan dengan hubungan antara dua atau lebih pelaku interaksi sosial ekonomi mencakup dinamika aturanaturan yang berlaku dan disepakati bersama oleh para pelaku interaksi, disertai dengan analisis mengenai hasil akhir yang diperoleh dari interaksi yang terjadi (Hendayana \& Wally, 2003).

Oleh karena itu maka dalam proses pengelolaan sumberdaya pesisir dan laut, pemerintah perlu memperhatikan masyarakat dan kebudayaannya, baik sebagai bagian dari subjek maupun objek pengelolaan, sehingga kondisi fisik dan alamiah dari sumberdaya serta proses pengelolaannya lebih terpadu dan efektif serta diterima oleh masyarakat. Sehubungan dengan itu maka kelembagaan adat yang terdapat di Kota Tidore Kepulauan telah menghadirkan suatu pendekatan pengelolaan sumberdaya pesisir dan lautan yang cukup baik untuk dikembangkan.

Terdapat lima tradisi dan kelembagaan yang menjadi kearifan lokal masyarakat berkaitan dengan pemanfaatan dan pelestarian sumberdaya pesisir dan laut yakni, tradisi Karo Kahiya di Desa Mare Gam, Fola Sow dan Jere di Desa Maitara, Cofa di Kelurahan Soasio dan Dowora serta Saihu di Kelurahan Tomalou dan Mareku. Adapun tradisi dan kelembagaan dimaksud dapat dijelaskan sebagai berikut:

\section{1) Karo Kahiya (Memanggil Lumba- Lumba)}

Memanggil Lumba-Lumba merupakan sebuah tradisi turun temurun yang dilakukan oleh masyarakat Desa Mare Gam. Ritual ini biasanya dilakukan di teluk berjarak kurang lebih $500 \mathrm{~m}$ ke arah Selatan dari Desa Mare Gam. Teluk ini diberi nama oleh masyarakat setempat dengan sebutan Kahiya Masolo (Teluk Lumba-Lumba). Kahiya dalam bahasa Tidore adalah ikan lumba-lumba dan masolo berarti teluk. Ritual ini dilakukan ketika terjadi gangguan di desa seperti wabah penyakit, bencana alam ataupun memenuhi hajat dari masyarakat setempat. Menurut kepercayaan 
masyarakat setempat Kahiya (ikan lumbalumba), adalah benteng (pelindung) bahkan sebagai bala tentara dalam menghadapi ancaman baik yang bersifat mistis maupun sebaliknya. Tradisi ini dilakukan dengan tujuan memohon keselamatan, restu dan perlindungan untuk desa dan anak cucu dari ancaman tersebut. Ritual hanya dapat dilakukan oleh orang-orang tertentu, yang secara turun temurun dibekali dengan kemampuan mistis untuk memanggil lumba-lumba. Ritual ini menjadi salah satu instrumen dalam pelestarian sumberdaya pesisir dan laut. Hal ini disebabkan karena dengan adanya ritual ini, teluk lumba-lumba (Kahiya Masolo) menjadi lokasi yang disakralkan dan dipercaya mengandung kekuatan mistis sehingga tidak dengan sembarangan setiap orang dapat melakukan aktivitas apapun di lokasi ini, tanpa adanya izin (idin-"bahasa tidore") terlebih dahulu. Dampak positif yang timbul yaitu masyarakat melindungi berbagai ekosistem pesisir dan laut yang berada di kawasan Teluk Kahiya Masolo. Ekosistem terumbu karang, lamun dan mangrove dengan berbagai biota asosiasinya terlindungi dari aktivitas ekploitasi oleh manusia. Walaupun sampai saat ini belum ada yang meneliti secara detail biodiversitas dari ketiga ekosistem ini karena masaalah izin dan pensakralan terhadap Teluk Kahiya Masolo, namun diyakini oleh masyarakat setempat ketiga ekosistem pesisir penting ini masih sangat baik.

\section{2) Fola Sow (Rumah Obat)}

Masyarakat Kota Tidore Kepulauan pada umumnya dan masyarakat Desa Mare Gam pada khususnya, masih mempercayai proses penyembuhan penyakit dengan pendekatan mistis dan supranatural. Fola Sow (Rumah Obat) merupakan tempat yang disakralkan oleh masyarakat setempat untuk mengobati berbagai penyakit. Setiap orang dalam komunitas tersebut yang mengidap penyakit medis maupun non medis, akan diobati dengan pendekatan pengobatan tradisional warisan leluhur yang bertempat di Fola Sow. Pada dasarnya di seluruh wilayah
Pulau Tidore, Pulau Mare, dan Maitara memiliki Fola Sow-nya masing-masing dengan lokasi penempatan yang berbedabeda. Khususnya pada beberapa tempat seperti di lokasi studi (Desa Mare Gam), Fola Sow (Rumah obat) terletak di kawasan ekosistem mangrove, atau tepatnya berada di dataran Teluk Kahiya Masolo. Ritual ini dilakukan ketika ada orang yang memerlukan bantuan pengobatan akibat penyakit yang dideritanya, maupun memohon obat dari Fola Sow agar dalam aktivitasnya tidak ditimpakan penyakit. Ritual ini dilakukan dengan cara memberi tumpeng dan membaca puja-puji untuk kesembuhan dan perlindungan dari berbagai penyakit. Posisi Fola Sow terletak di kawasan ekosistem mangrove menjadikan kawasan ini dijaga dan dilestarikan. Hal ini disebabkan masyarakat turut mensakralkan kawasan mangrove tersebut karena masyarakat mempercayai bahwa arwah leluhur bersemayam, sehingga tidak seorang pun yang berani merusak sumberdaya ekosistem mangrove. Dalam konteks ini maka kawasan hutan mangrove di Teluk Kahiya Masolo tumbuh dan berkembang dengan baik. Selain itu, pemanfaatan hutan mangrove oleh masyarakat setempat dilakukan secara baik dan bijaksana. Kegiatan penebangan pohon mangrove dilakukan hanya pada pohonpohon yang sudah mati.

\section{3) Jere (Kuburan Leluhur)}

Jere merupakan tempat yang dikeramatkan berupa kuburan para leluhur. Semua masyarakat desa dan kelurahan di Pulau Tidore dan Pulau Maitara masing-masing memiliki Jere (kuburan yang dikeramatkan) dnegan tempat yang berbeda-beda pula. Pada lokasi studi (Desa Maitara) posisi Jere terletak di kawasan hutan Mangrove. Masyarakat di Pulau Maitara meyakini Jere merupakan tempat bersemayam arwah para leluhur, memiliki kekuatan mistis dan supranatural yang tinggi. Hanya orangorang tertentu yang dapat berkunjung ke tempat tersebut. Jere di Pulau Maitara terletak di beberapa titik dan tersebar di 
pesisir pantai Pulau Maitara. Lokasi-lokasi ini disakralkan dan sangat dihormati, sehingga sumberdaya alam dan lingkungan di kawasan Jere tersebut terjaga dengan baik. Masyarakat tidak berani mengeksploitasi sumberdaya alam dan lingkungan sekitar kawasan Jere. Penghormatan masyarakat atas Jere tersebut bernilai strategis, sehingga sumberdaya ekosistem mangrove, lamun dan terumbu karang masih terjaga walaupun hanya pada kawasan Jere. Masyarakat di Pulau Maitara memanfaatkan sumberdaya pesisir untuk kebutuhan seharihari seperti pembangunan rumah dan lainnya. Kayu dari pohon mangrove digunakan sebagai material untuk pembangunan rumah masyarakat, sedangkan batu diambil dari terumbu karang. Pemanfaatan terumbu karnag dan pohon mangrove tersebut cukup tinggi, sehingga dapat merusak ekosistem pesisir penting. Kegiatan eksploitasi ini dilakukan jauh dari kawasan Jere.

\section{4) Cofa (Metode Penangkaran Ikan)}

Cofa atau tempat berteduhnya ikan sebelum dipancing merupakan suatu tempat yang dibuat oleh nelayan di lokasi studi yang bahannya terdiri dari kayu, bambu dan pelepah daun kelapa. Pembuatan Cofa dimaksudkan untuk penangkapan ikan dengan alat tangkap pancing dengan target tangkapan utama ikan Tude/Selar kuning (Selaroides leptolepis). Hasil pengamatan menunjukkan bahwa pembuatan Cofa oleh masyarakat setempat sangat memperhitungkan ukuran panjang dan lebar. Ukuran panjang dan lebar Cofa yang dibuat haruslah ganjil sesuai dengan kemampuan bahan yang dipersiapkan oleh nelayan. Masyarakat setempat mempecayai bahwa ukuran-ukuran ganjil akan membuat tempat (Cofa) selalu dimasuki oleh ikan untuk bernaung atau siap dipancing oleh nelayan dan tidak akan pernah habis. Selain itu, pengambilan bahan-bahan pembuat Cofa seperti bambu dan daun kelapa harus dilakukan pada waktu surut. Hal ini dipercayai dapat membuat ikan terkonsentrasi pada tempat tersebut dan tidak akan keluar. Pembuatan Cofa juga memiliki ritual tersendiri mulai dari pembuatan hingga Cofa siap untuk dioperasikan. Setelah Cofa siap dioperasikan, maka ritual selanjutnya adalah memanggil ikan target tangkapan untuk datang bernaung di bawah Cofa. Cofa biasanya dibuat di daerah tanjung dengan lokasi yang tidak ada ekosistem terumbu karang, sehingga dikategorikan ramah terhadap lingkungan. Kekuatan Cofa untuk menarik gerombolan ikan yang datang mendiaminya, dipercayai terletak pada kemampuan lokal genius dalam membuat ritual memanggil ikan. Hingga saat ini, Cofa masih ada dan tradisi ini masih terpelihara. Kearifan ini sangat bermafaat karena usaha penangkapan yang dilakukan hanya menggunakan pancing, yang sudah tentu sangat selektif terhadap hasil tangkapan serta ramah lingkungan (Chaliluddin, $d k k ., 2019$ ).

\section{5) Saihu (Pemimpin Nelayan dalam Suatu Pelayaran)}

Nelayan di lokasi studi secara kelembagaan membentuk kelompok nelayan yang dipimpin oleh seorang Saihu. Orang yang akan diangkat menjadi Saihu biasanya berasal dari garis keturunan Saihu. Secara turun temurun Saihu dididik untuk memiliki ilmu spiritual yang tinggi. Selain itu, Saihu juga memahami ilmu falak, ilmu perbintangan, kemampuan membaca tandatanda alam tentang adanya sumberdaya ikan dengan berbagai jenis. Saihu biasanya memimpin ritual sebelum melakukan kegiatan melaut. Para nelayan berdoa dengan membaca doa-doa khusus, guna mendapat pertolongan dari Tuhan Yang Kuasa dalam melakukan operasi penangkapan. Saihu bertangung jawab atas keselamatan para nelayan yang menjadi anggota dalam sebuah operasi penangkapan ikan yang dipimpinnya. Beberapa pelarangan yang sangat dikontrol oleh Saihu pada saat operasi penangkapan ikan dilakukan adalah larangan membuang sampah ke laut, larangan membuang sisa 
hasil tangkapan ke laut, dan larangan menangkap burung, ikan hiu dan lumbalumba. Larangan-larangan ini biasanya diberitahukan sebelum operasi penangkapan dilakukan. Kesadaran ini wajib dijaga dan dilestarikan oleh seorang Saihu dari generasi ke genarasi, karena kehidupan mereka sangat bergantung dengan hasil tangkapan ikan di laut. Saihu akan mengatur waktu pelayaran, menentukan lokasi penangkapan ikan dan mengatur tata cara pembagian hasil tangkapan. Bentuk-bentuk pelarangan yang disebutkan merupakan wujud pelestarian sumberdaya dan lingkungan laut.

\section{Pengelolaan Sumberdaya Berbasis Kelembagaan Adat}

Pengelolaan sumberdaya pesisir dan lautan oleh masyarakat Kota Tidore Kepulauan melalui pelestarian nilai-nilai tradisi dan kelembagaan adat bermakna ganda bagi kelangsungan hidup masyarakat setempat. Hal ini dapat dicermati dengan keberadaan masyarakat yang tetap memegang teguh tradisi dan kelembagaan adatnya, bersamaan dengan itu masyarakat mendapatkan nilai lebih pelestarian sumberdaya pesisir dan lautan berupa ekosistem pesisir yang lestari.

Keberadaan tradisi dan kelembagaan adat tersebut di atas memiliki keterkaitan yang signifikan dengan pengelolaan sumberdaya pesisir dan lautan yang pada gilirannya dapat menguntungkan masyarakat pesisir itu sendiri. Sehubungan dengan itu (Dahuri et al., 2001), kelembagaan sebagai institusi, terdiri dari tiga aspek yaitu : 1) aparatur yang bekerja di lembaga tersebut, 2) fasilitas ruang, peralatan dan bahan, serta fasilitas lainnya untuk mengoperasikan lembaga, dan 3) dana operasional untuk membiayai kegiatan lembaga tersebut. Sedangkan pelembagaan nilai-nilai adalah memasyarakatkan hasil yang dikerjakan oleh lembaga tersebut kepada masyarakat atau pengguna jasa lembaga tersebut. Nilai-nilai yang dilembagakan dapat berupa peraturan perundang-undangan, peraturan daerah, tataruang wilayah pesisir dan lautan, pedoman perencanaan dan bentuk-bentuk lainnya abik secara tertulis maupun tidak tertulis.
Keberlanjutan sumberdaya alam dan lingkungan sangat ditentukan oleh interaksi antara manusia dan lingkunganya. Pada masa lalu, ketika manuisa masih menggunakan berbagai alat tradisional untuk mengeksploitasi sumberdaya alam, ternyata manusia masih tunduk, patuh dan taat kepada tata nilai lokal yang diwariskan oleh para leluhurnya. Manusia masih memiliki kesadaran untuk menjaga dan memelihara alam, sehingga kerusakan alam tidak signifikan terjadi dan bahkan keberlanjutannya dapat terjaga dengan baik. Pelestarian lingkungan dan sumberdaya alam akan tercipta jika manusia secara kolektif memiliki kearifan dalam memperlakukan alam dan lingkungannya.

Kearifan lokal masyarakat Tidore dapat menjadi salah satu bagian dari spirit pengelolaan sumberdaya pesisir dan laut. Bukan hanya difokuskan pada tradisi, keyakinan dan kepercayaannya serta tata nilai lokalnya semata, namun terletak pada sistem yang dibangun dalam tradisi tersebut sehingga terjaga dan terpelihara hingga saat ini. Tradisi dan kelembagaan adat ini memberi makna tentang masyarakat lokal yang dengan arif dan bijaksana mampu menjaga, merawat dan melestarikan sumberdaya alam dan lingkungannya. Masyarakat tidak pernah berfikir bahwa apa yang mereka lakukan berdampak positif bagi lingkungan pesisir dan lautan, namun mereka lakukan karena meyakini, mempercayai dan menjalankan titah para leluhur sebagai warisan nilai budaya. Hal ini juga merupakan bentuk pertanggung-jawaban masyarakat terhadap generasi mendatang agar mewarisi nilai-nilai yang telah ada dari para leluhur sekaligus bersama-sama menjaga kelestarian lingkunan pesisir dan laut. Tradisi ini menunjukkan suatu pola kelembagaan yang dianut oleh masyarakat Kota Tidore pada masa lalu dapat diaplikasikan dalam pengelolaan sumberdaya pesisir dan lautan pada masa sekarang. Pada dasarnya, potensi sumberdaya alam dang lingkungan yang dimiliki saat ini merupakan titipan dari generasi mendatang.

Sehubungan dengan itu maka kelembagaan diadakan untuk menciptakan, menumbuhkan, mengembangkan dan mengubah kehidupan yang senantiasa lebih baik dari hari 
ke hari. Kelembagaan merupakan proses untuk melembaganya nilai-nilai kemanusiaan (humanity), kebenaran (righteousness), kesopanan (civility), kearifan (wisdom), kepercayaan (trust), dan perdamaian (peace) (Purwaka, 2006; Syahyuti, 2003). Pengelolaan pesisir dan lautan yang dilakukan oleh masyarakat Kota Tidore telah memiliki tata kelembangaan yang didalamnya sudah termasuk perangkat hukum, ekonomi, hubungan antara pelaku yang terlibat dalam pemanfaatan sumberdaya pesisir dan laut, sehingga akselerasi yang dimaksudkan dapat menguntungkan semua pihak termasuk pemanfaatan sumberdaya pesisr dan lautan yang berkelanjutan.

\section{KESIMPULAN DAN SARAN}

Berdasarkan hasil penelitian maka dapat disimpulkan bahwa terdapat lima kearifan lokal yang tetap terjaga oleh masyarakat Kota Tidore Kepulauan. Kelima tradisi tersebut merupakan warisan dari para leluhur dalam pengelolaan sumberdaya pesisir dan laut, yakni Karo Kahiya (Memanggil Lumba Lumba), Fola Sow (Rumah Obat), Jere (Keramat), Cofa (Penangkaran Ikan) dan Saihu (Pemimpin/Nakoda dalam Operasi Penangkapan Ikan).

Pendekatan pengelolaan sumberdaya pesisir dan lautan dengan tata cara tradisi dan kelembagaan telah memberikan dampak yang sangat signifikan (sangat efektif) bagi masyarakat setempat dalam pemanfaatan sumberdaya pesisir dan lautan yang berkelanjutan. Pendekatan ini juga memberikan makna ganda baik terhadap pengaturan tata cara pemanfaatan serta pelestarian sumberdaya alam maupun pelestarian tradisi dan kelembagaan adat istiadat setempat. Adapun saran yang dapat disampaikan yaitu perlunya penelitian lanjutan tentang kondisi ekonomi masyarakat pesisir di Kota Tidore Kepulauan.

\section{DAFTAR PUSTAKA}

BPS Kota Tidore Kepulauan, 2020. Kota Tidore Kepulauan dalam Angka. Penerbit Badan Pusat Statistik Kota Tidore Kepulauan, Provinsi Maluku Utara.
Chaliluddin, M.A., M. Ikram, D. Rianjuanda. 2019. Identifikasi Alat Penangkapan Ikan Ramah Lingkungan Berbasis CCRF di Kabupaten Pidie, Aceh. Jurnal Galung Tropika 8(3): 197-208. DOI: http://dx.doi.org/10.31850 /jgt.v8i3.504.

Carter, J.A. 1996. Introductory Course on Integrated Coastal Zone Management (Training Manual). Pusat Penelitian Dan Sumberdaya Alam dan Lingkungan Universitas Sumatera Utara, Medan dan Pusat Pusat Penelitian Sumberdaya Manusia dan Lingkungan Universitas Indonesia, Jakarta, Delhousie University, Enveiromental Studies Centres Development in Indonesia Project.

COREMAP-LIPI. 1997. Petunjuk Pelaksanaaan Pengelolaan Berbasis Masyarakat. Dokumen Buah Kerjasama antara Lembaga Ilmu Pengetahuan Indonesia, Pusat Penelitian dan Pengembangan Oseanologi, Proyek Rehabilitasi dan Pengelolaan Terembu Karang dan PT ECOLINK UTAMA. 19 hal.

Cresswel, J. W. 2010. Research Design; Pendekatan Kualitatif, Kuantitatif Dan Mixed. Yogyakarta: Pustaka Pelajar.

Dahuri, R. Rais, J., Ginting, S.P., dan Sitepu, M.J. 2001. Pengelolaan Sumberdaya Wilayah Pesisir dan Lautan secara Terpadu. Cetakan Kedua : ISBN 979-408381-X. PT. Pradnya Paramita, Jakarta. 328 hal.

Dewi A. A. I. A. A. 2018. Model Pengelolaan Wilayah Pesisir Berbasis Masyarakat: Community Based Development. Jurnal Penelitian Hukum "De Jure" p-issn 14105632, e-issn 2579-8561.

Gaspersz, S. 2000. Analisa Sosial-Budaya Dan Refleksi Teologis Terhadap Heka-Leka Di Naku Pulau Ambon. Universitas Kristen Satya Wacana.

Hendayana, R \& F. Wally. 2008. Analisis Kelembagaan Pasar Input dan Output Usaha Ternak Rakyat; Kasus pada Usaha Ternak Rakyat di Nabire, Papua. SOCA: Jurnal Sosial Ekonomi Pertanian 8(1): 1-10. https://ojs.unud.ac.id/index.php/ soca/article/view/4174.

Irrubai, M. L. 2019. Implementasi Nilai-nilai Kearifan Lokal Awik-awik Desa Sesaat dalam pembelajaran Ilmu Pengetahuan Sosial. SOSIO DIDAKTIKA 6(2): 96-109. p-ISSN: 2356-1386, e-ISSN: 2442-9430.

Latuconsina, H. 2009. Eksistensi Sasi Laut Dalam Pengelolaan Perikanan Berkelanjutan Berbasis Komunitas Lokal Di Maluku. 
TRITON: Jurnal Manajemen Sumberdaya Perairan 5(1): 63-71.

Najamudin, W., E. Reppie, L. Manoppo. 2015. Pengelolaan Sumberdaya Ikan Lema (Ratrelliger kanagurta) yang Berbasis Kearifan Lokal di Kampung Warsamdin dan Lopintol, Distrik Teluk Mayalibit, Provinsi Papua Barat. Jurnal Ilmu dan Teknologi Perikanan Tangkap 2(1): 28-32, ISSN 23374306.

Nikijuluw V.P.H. 1994; Sasi sebagai Suatu Pengelolaan Sumberdaya Berdasarkan Komunitas ( PSBK) di Pulau Saparua, Maluku. Jurnal Penelitian Perikanan Laut. 93:79-92.

Niman, E. M. 2019. Keraifan Lokal dan upaya Pelestarian Lingkungan Alam. Jurnal Pendidikan dan Kebudayaan Missio 11(1): 91-106.

Juliani. 2014. Pemanfaatan Sumberdaya Perikanan Berbasis Kearifan Lokal Di Wilayah Pesisir Kabupaten Kutai Timur, AGROINTEK 8 (2): 104-112. e-issn 2527-5410. DOI: https:// doi.org/10.21107/ agrointek.v8i2.2011.

Persada, N. P. R., F. M. Mangunjawa, I. S.L. Tobing. 2018. Sasi Sebagai Budaya Konservasi Sumberdaya Alam di Kepulauan Maluku. Jurnal Ilmu dan Budaya 41 (59): 6869-6900.

Purwaka, T.H. 2006. Bunga Rampai Analisis Pengembangan Kapasitas Kelembagaan Kelautan dan Perikanan. Bahan Perkuliahan Pascasarjana IPB. Bogor.

Satria, A \& A. Mony. 2019. Dinamika Praktek Sasi Laut di Tengah Transformasi Ekonomi dan Politik Lokal. Sodality: Jurnal Sosiologi Pedesaan 7(2): 143-152. DOI: $10.22500 /$ sodality.v7i2.27165.
Sufia, R., Sumarmi, Ach. Amirudin. 2016. Kearifan Lokal Dalam Melestarikan Lingkungan Hidup (Studi Kasus Masyarakat Adat Desa Kemiren Kecamatan Glagah Kabupaten Banyuwangi). Jurnal Pendidikan: Teori, Penelitian dan Pengembangan 1(4): 726-731.

Sugiyono. 2018. Metode Penelitian Kuantitatif Kualitatif dan $R \& D$. Bandung, ALFABETA.

Sulaiman. 2013. Prospek Hukum Adat Laut Dalam Pengelolaan Perikanan di Kabupaten Pidie Jaya Provinsi Aceh. Yustisia 2(3): $15-22$.

Supusesa, R. 2012. Eksistensi Hukum Delik Adat Dalam Perspektif Pembaharuan Hukum Pidana Di Maluku Tengah. Mimbar Hukum 24(1):41-54.

Suradisastra, K. 2008. Strategi Pemberdayaan Kelembagaan Petani. Forum Penelitian Agro Ekonomi 26(2): 82-91.

Syahyuti. 2003. Alternatif Konsep Kelembagaan Untuk Penajaman Operasionalisasi Dalam Penelitian Sosiologi. Forum Penelitian. AGRO EKONOMI, 21(2): 113-127, P-ISSN: 02164361 E-ISSN: $2580-2674$.

Talakua, W. 2011. Perubahan Produktivitas Kawasan Sasi Lompa Di Negeri Haruku Kecamatan Pulau Haruku Kabupaten Maluku Tengah. TRITON: Jurnal Manajemen Sumberdaya Perairan 7(2): 71-78. ISSN 1693-6493.

Ulfa, M. 2018. Persepsi Masyarakat Nelayan Dalam Menghadapi Perubahan Iklim (Ditinjau Dalam Aspek Sosial Ekonomi). Jurnal Pendidikan Geografi: Kajian, teori dan Praktik dalam Bidang Pendidikan dan Ilmu Geografi 23(1): 41-49. 